\title{
"Children of a Lesser God:" The Effects of Communication and Interaction Patterns on Student Spiritual Identity at a Church-Related University
}

\author{
G. L. Forward ${ }^{1}$, Jenay Moore ${ }^{2}$, Megan Richardson ${ }^{2} \&$ Marie Shimansky ${ }^{2}$ \\ ${ }^{1}$ Organizational Communication, Point Loma Nazarene University (author names are alphabetical) \\ ${ }^{2}$ Department of Communication and Theatre at PLNU \\ Correspondence: G. L. Forward, Point Loma Nazarene University, Department of Communication \& Theatre, 3900 \\ Lomaland Drive, San Diego, CA 92106, USA
}

Received: January 30, 2014 Accepted: February 17, 2014 Available online: March 12, 2014

doi:10.11114/smc.v2i1.326

URL: http://dx.doi.org/10.11114/smc.v2i1.326

\begin{abstract}
Social identity theory provides a frame for studying the relationship between communication and interaction patterns and college student spirituality. In this project we measured the self-perceived spirituality, personal attitudes toward self and others, and communication of a convenience sample of $\mathrm{N}=149$ college students at a private, four-year, church-related institution in southern California. We found that traditionalism, a stable belief in the values and attitudes reflected in how one is raised, explained $60 \%$ of student spirituality scores. Gregariousness, the measure of connectedness a participant feels to a group or to the institution, explained an additional $5.2 \%$ of student spirituality. Additional post hoc analysis revealed a statistically significant negative association between rebelliousness and both traditionalism and spirituality scores. We also utilized two t-Tests to compare lower and upper class students, as well as females and males, on the variables of interest. Upper class students reported higher scores on spirituality, life satisfaction, gregariousness, positive attitude toward tradition, and self-disclosure whereas lower class members scored higher only in rebelliousness. In addition, females scored higher on all of the variables measured in comparison to males, with the exception of rebelliousness. Findings demonstrated that education at a private Christian institution did not erode student spirituality and may have strengthened spirituality over the four year period.
\end{abstract}

Keywords: college students, spirituality, satisfaction, gregariousness, traditionalism, self-disclosure, rebelliousness, Christian higher education

"For why is all around us here

As if some lesser god had made the world

But had not force to shape it as he would?"

--Alfred, Lord Tennyson, Idylls of the King

\section{Introduction}

Adolescence is characterized by both physical and mental development, as well as the emergence of personal identity, beliefs, and values (Mullikin, 2006). One area of special importance to many parents concerns religious traditions and practices and the spiritual identity of their children (Welch \& Mellberg, 2008). Identity in general, and spiritual identity in particular, is a developmental process that consists of both internal and external information processes predicated on family modeling, social interaction, and the inevitable self-other comparisons that occur as a result of those interactions (McNamee, 2011). As such, this project is guided by social identity theory (Taijel \& Turner, 1986) and communication research that suggests identity is discursively shaped and manifest in social interaction patterns with other individuals and groups (Silva \& Sias, 2010). Additionally, surveys indicate that some adolescents become more spiritually engaged as they approach adulthood, while others grow disillusioned, skeptical, or indifferent to their religious upbringing (Barna Group, 2003). This is especially true for those young people who move away from home to attend college and experience greater religious diversity or even hostility toward religion (Bryant, Choi, \& Yasuno, 2003). Since much of the existing literature regarding the spiritual identity of college students is theoretical in nature, Regnerus (2003) suggests additional empirical investigation. Therefore, this study aims to assess communication and interaction patterns 
which contribute to, or hinder, the spirituality of students in the context of a private Christian university.

Although spirituality has received increased attention in the social sciences in recent years, the spiritual identity, attitudes, and practices of college students has been of concern to higher education in the U.S. since its origins (Astin, Astin, \& Lindholm, 2011; Birkholz, 1997; Forward, Czech, \& Allen, 2007). We conducted this study at an evangelical Christian university associated with the Council for Christian Colleges \& Universities (CCCU) (Clark, 2002; Dennis, Muller, Miller, \& Banerjee, 2004). CCCU institutions make spiritual growth and development an explicit focus and mission of the university (Council for Christian Colleges \& Universities, 2010). Many parents and students select a private Christian university specifically because it offers a "safe" Christian culture and environment (Henck, 2011). Universities of this type typically require academic classes in Bible and religion, promulgate a stringent behavioral rule system based on conservative Christian values, and require frequent chapel attendance (Eckstein \& Truman, 2002). Although some students view these required activities as helpful in navigating their spirituality, others report that the "forced" nature of these requirements actually hinders spiritual development (Fisler, Agati, Chance, Donahue, A.E., Donahue, G.A., Eickhoff \& Foubert, 2009). Since spirituality, and its effects, exists at both the individual and community levels, and plays an important role in personal identity (Kind, 2003), we want to explore the effects of communication behaviors (gregariousness, self-disclosure), personal attitudes (traditionalism, satisfaction, rebelliousness), and demographics (class rank, sex) on scores of student spirituality.

\section{Literature Review}

\subsection{Spirituality in Young Adulthood}

According to scholars, spirituality refers to the internal process related to the search for personal wholeness, authenticity, and connectedness to self and other, derived from openness toward a higher power that transcends human knowledge or experience (Bryant \& Astin, 2008). As such, spirituality is an omnibus construct that addresses fundamental questions about the meaning and purpose of life, and may or may not, involve organized religion (Judge, 1999). However, for many people, spirituality is manifested and expressed in the context of formal beliefs and practices associated with an identifiable religious denomination (Granqvist \& Hagekull, 2003). Certainly, in conservative evangelical universities, we can assume that spirituality and religion are closely aligned for most students and parents (Henck, 2011). Indeed, both Mullikin (2006) and Ma (2003) assert that this is a primary motivation for choosing to attend a Christian college or university.

We know that conservative Protestant universities exist for the express purpose of fostering spiritual growth and religious devotion in its members (Glanzer, Carpenter, \& Lantinga, 2011). We also know that young adulthood is a prominent time in which individuals either become engaged in religious practices or become disenchanted with religion (Eckel, 2009). In fact, according to Astin (2004), about one-third of the students she surveyed reported feeling "disillusioned" with their religious upbringing although others established positive, personally meaningful spiritual beliefs and practices. This young adult period, ranging from 18-25 years of age, is a critical time when young adults strive to find meaning and purpose and strongly desire deep relationships and connectedness (Hart, Limke, \& Budd, 2010). College represents an important period when young adults are more cognitively aware and able to determine and question ideas on their own (Glanzer, Carpenter, \& Lantinga, 2011). This presents universities with a tremendous opportunity to provide students with the tools to search and discover what they believe regarding their own spirituality.

\subsection{Spirituality and Higher Education}

Astin (2004) suggests that looking at the internalized attitudes of students and observable patterns of interpersonal behavior provides an opportunity to explore the connection between spirituality and higher education. Her research suggests that if universities (both secular and religious-affiliated) place an importance on spirituality, they will strengthen the sense of connectedness with peers, faculty, and the institution as a whole. The enrichment found in a sense of community can help combat the sense of loneliness and fragmentation university students sometimes report, and may ultimately help students find more meaning in their lives (Bryant \& Astin, 2008). This suggests that spiritual development in a university setting is critical in creating full-functioning adults with a sense of connectedness and community, as well as generalized life satisfaction (Lee, 2002; Mannoia, 2000).

Ma (2003) asserts that the core responsibility of Christian universities is to create educational experiences that develop young Christian adults who will display mature characteristics of a Christian in terms of both self-identity and interpersonal behavior. She also suggested that Christian universities have a unique opportunity to facilitate mature Christian character, religious attitudes, and interpersonal behavior patterns through the college environment (Ma, 2003). Nonetheless, although it is agreed that developing a sense of spirituality is important in the Christian university setting, there is no specific formula on how these universities go about accomplishing this goal (Griffin, 2004). Below we identify variables that may help to explain those personal attitudes and behavior patterns that make a positive contribution to student spirituality in the conservative Christian university context. 


\subsection{Attitudes toward Tradition}

According to research by King and Boyatzis (2004), 95\% of U.S. youth acknowledge a belief in God, $75 \%$ verbalize that they attempt to follow the principles of their religion, $42 \%$ claim to pray regularly and a little more than half of the group say they are or have been part of a religiously-affiliated youth group. These statistics suggest a widespread belief in God, a relatively stable participation in organized religion, and the role of spiritual identity in adolescent self-development (Smith, Denton, \& Regnerus, 2002). These data also imply that many students arrive at college with a fairly stable set of beliefs concerning spirituality and religion, predicated on parenting patterns and traditions established in childhood.

\subsubsection{Traditionalism}

Sloat (1986) suggests that parental interaction and communication with their children may be the most influential factor in a child's attitudes toward spirituality and religion. Family traditions created in childhood influence how one understands spirituality, God, religion, and the role these should play in life (Granqvist \& Hagekull, 2003). Open communication, involved parenting, and talking about spirituality at home increases the likelihood of developing a stable spiritual identity as well as positive attitudes toward family traditions and religious practices.

Gunnoe, Hetherington and Reiss (1999) note that many parents believe that obedience to parental authority will teach children to submit to God. Others have argued that the authoritative (as opposed to authoritarian) parenting style is a good way to convey religious values (Forward, Sansom-Livolsi, \& McGovern, 2008). One study found that these traditional practices were ingrained in these students' lives as "just how they were raised" (Welch \& Mellberg, 2008). The study also suggested that traditional attitudes toward God, prior church attendance, and "intrinsic religiosity" had a positive influence on student spiritual development (Welch \& Mellberg, 2008, p.11). An individual's attitude toward traditionalism may be a key in determining student spirituality because of the effect it has on a wide array of beliefs, expectations, and values.

\subsubsection{Rebelliousness}

One of the main challenges that a young adult faces is reconciling the natural tension between obedience and autonomy (Baumbach, Forward, \& Hart, 2006). Bukobza (2009) proposes that for the first time in their lives, some late adolescents and young adults will go against the values in which they were brought up. She suggests that these individuals can become rebellious in their "attitudes, emotions and actions towards authority" and that this rebelliousness can be related to risky behavior (p. 160).

According to Greydanus, Pratt, Patel and Sloane (1997), rebelliousness is defined as repeated opposition to the "rules, values, and morals of the family, school, community or society" (p.162). In these instances, young adults could adopt behaviors such as binge drinking, reckless driving, unsafe sex, and drug use, as behaviors exhibiting adulthood (Bukobza, 2009). These signs of rebelliousness mostly stem from rejecting parental influence and social expectations. In fact, a number of studies have found an inverse relationship between spirituality and high-risk behaviors in adolescents (Young, Cashwell, \& Shcherbakova, 2000).

\subsection{Communication: Self-Disclosure and Gregariousness}

According to Greene, Derlega and Mathews (2006), interpersonal relationships are communication phenomena based on self-disclosure and interpersonal connectedness. This is predicated on the idea that self-disclosure is an integral part of any relationship and meaningful relationships are an integral part of life satisfaction. Prothero (2007) suggests that religion is often a large factor in shaping people's values and that the ability to be open about one's spirituality can be beneficial to the individual. His findings suggest that self-disclosure may be a key factor in one's spirituality. On an individual level, Greene, Derlega and Mathews (2006) discuss the importance of self-disclosure because it is linked to increased social support, as well as positive self-worth. Closely related to self-disclosure is the degree to which one is gregarious. As used here, gregariousness is the measure of connectedness that one feels toward a group or institution in which one is involved (Peterson \& Seligman, 2004). Additionally, research suggests that self-disclosure and gregariousness can make a positive contribution to one's psychological well-being and overall life satisfaction (Maltby \& Day, 2003).

\subsection{Life Satisfaction}

Satisfaction is described by Okulicz-Kozaryn (2010) as "happiness" and a sense of fulfillment in life. In his study looking at the relationship between religiosity and life satisfaction, he found a bimodal relationship suggesting that religious people are either extremely satisfied or dissatisfied with life, but not in the middle. Okulicz-Kozaryn's (2010) research also compared social religiosity and individual religiosity, with the former being associated with greater life satisfaction. According to his findings, attending church correlates greatly with life satisfaction and contributes significantly to the need to belong and to be valued. 


\subsection{Evaluating Demographic Differences}

\subsubsection{Class Rank}

Many studies suggest that the experience of underclassmen in college differs greatly from the experience of upperclassman. A study done by Forward, Daugherty, Michel and Sandberg (2009), suggest that first-year and sophomore students have higher levels of organizational commitment because they are newer to the organization and thus have not been exposed to the policies, requirements, frustrations with the bureaucracy as long as seniors have. They propose that first-year and sophomore students will be enthusiastic about becoming a part of their new environment and all that that encompasses (Forward, et al., 2009). On the other hand, seniors who have been in their institutional environment for several years may feel suffocated and restricted which in turn may make them enthusiastic about leaving school. These feelings that seniors experience may come from negative encounters with the organization or feeling less obligated to the institution (Forward, et al., 2009). Research by Bryant, Choi, and Yasuno (2003) found that first-year students became less involved in religious behavior and also reported that their spirituality decreased over their initial year of college. According to Ma (2003), Christian higher education could benefit from treating upper and underclassman independently. First-year and sophomore students may be experiencing a significantly different university than what junior and senior students are experiencing.

\subsubsection{Sex}

According to Smith, Faris, Denton and Regnerus (2003), women, no matter their age, tend to have higher scores on spirituality and religiosity when compared to men. Females as a whole are also more inclined to talk about religion and spirituality more than men (Forward, et al., 2009). This knowledge also hints at a higher level of self-disclosure among women. According to Welch and Mellberg (2008), because of these apparent differences between men and women they suggest that "developmental, gender-specific programs" should be developed for students at Christian universities to help address spiritual growth (p. 159). Welch and Mellberg (2008) also stress the importance of approaching males and females differently when encouraging and discussing the spiritual growth of their students while also taking into account the necessity for different programs and approaches in spiritual growth depending on class rank.

\subsection{Research Questions and Hypotheses}

RQ1: What communication (self-disclosure, gregariousness), personal attitudes (traditionalism, satisfaction, rebelliousness), and demographic variables influence student spirituality?

RQ 2: Are there differences in student communication and personal attitudes based on class rank (underclassman, upperclassmen)?

H1: Underclassmen will score higher in spirituality than upperclassmen.

H2: Females will score higher than males on spirituality, satisfaction, gregariousness, and traditionalism and will score lower than males on rebelliousness.

\section{Method}

\subsection{Research Participants}

The population for this project consisted of a convenience sample of undergraduate college students enrolled in a conservative, Protestant university in Southern California. Demographically, our respondents $(N=149)$ ranged in age from 18 to 42 years of age with a mean age of $20(S D=2.39)$. In addition, our sample included $n=60$ underclassmen (freshman and sophomores) and $\mathrm{n}=89$ upperclassmen (juniors and seniors). There were nearly twice as many females $(\mathrm{n}=98,66 \%)$ as males $(\mathrm{n}=51,34 \%)$ and $79 \%(\mathrm{n}=118)$ were Caucasian and another $10 \%(\mathrm{n}=15)$ identified themselves as Hispanic. All of these numbers closely approximate the undergraduate population of the university as a whole.

\subsection{Research Procedures}

We designed a three-page, 46-item survey instrument to measure spirituality, satisfaction with life, gregariousness, attitude toward tradition, self-disclosure, and rebelliousness, as well as several demographic markers. We utilized Likert-type questions which consisted of a five-point metric scaled from 1 (strongly disagree) to 5 (strongly agree). Subsequent to IRB approval, we conducted a pilot test to assess the reliability and clarity of our questions. Based on these results we made modifications to the questions that negatively affected our reliability. We then distributed our surveys to a convenience sample which totaled $\mathrm{N}=149$ usable surveys.

\subsection{Instrumentation}

All survey questions were taken from pre-existing instruments that had been previously tested for reliability and validity. In order to increase participation and reduce participant fatigue, we limited our survey to three pages including several demographic questions such as age, class rank, ethnicity, and sex. The survey generally took five to ten minutes to 
complete. The internal constancy of our measures was assessed using Cronbach's alpha. Nunnally (1978) has suggested that an alpha of .60 or higher, should be considered acceptable in social science research. All of our measures were above .70 with most above .80 . Table 1 below shows the mean, standard deviation and alpha for all of the summated variables measured (Blaikie, 2003). Table 2 contains the correlation matrix for all of the summated variables.

Table 1. Summary Data

\begin{tabular}{llll}
\hline Variable & Mean & SD & Alpha \\
\hline Spirituality & 4.48 & .58 & .83 \\
Life Satisfaction & 3.95 & .66 & .77 \\
Gregariousness & 4.05 & .65 & .87 \\
Traditionalism & 3.96 & .79 & .83 \\
Self-disclosure & 3.48 & .68 & .83 \\
Rebelliousness & 2.29 & .69 & .76 \\
\hline
\end{tabular}

\subsubsection{Spirituality}

Spirituality was measured using seven items from Peterson and Seligman's (2004) Values in Action Inventory. This instrument measures an individual's spirituality, and tests if it defines who they are. Examples of questions used to measure a participant's level of spirituality were: "Keep my faith even during good times" and "Know that my beliefs make my life important." A negative worded question used was: "not believe in a universal power or God." The higher a participant scores in spirituality the higher probability that the participant believes in a universal God, practices religion, and trusts that their beliefs make his/her life important $(\mathrm{M}=4.48 ; \mathrm{SD}=58$; alpha $=.83)$.

\subsubsection{Life Satisfaction}

Satisfaction indicates the level of contentment an individual feels they possess within their life. In relation to our study, it measured the contentment a participant feels while attending a religiously affiliated university. This variable was measured using six questions from Cloninger, Przybeck, Svrakic, and Wetzel's (1994) Temperament and Character Inventory. An example of a negatively worded question used in our survey was: "Feel that others at school have a hard time understanding me" $(\mathrm{M}=3.95 ; \mathrm{SD}=.66$; alpha=.77).

\subsubsection{Gregariousness}

Gregariousness was measured using Jackson, Paunonen, and Tremblay's (2000) Six Factor Personality Questionnaire. Questions were worded to measure the degree a participant feels connected to individuals, groups, or to the institution as a whole. High scores on the questionnaire suggest high levels of gregariousness or connectedness. Here is an example question of the eight taken from this questionnaire: "Feel comfortable around people at school." An example of a negatively worded question is: "Keeps others at a distance" $(\mathrm{M}=4.05 ; \mathrm{SD}=.65 ;$ alpha=.87).

\subsubsection{Traditionalism}

Traditionalism measures agreement with the theory that all moral and religious truth comes from a divine revelation that has been passed on by tradition. This was measured using seven items from Jackson's (1994) Personality Inventory-Revised. Example questions included: "I believe in Divinely-revealed truth" and a negatively worded question was "I tend to doubt religious absolutes." ( $\mathrm{M}=3.96 ; \mathrm{SD}=.79$; alpha=.83).

\subsubsection{Rebelliousness}

Rebelliousness explains the level of defiance in a person's behavior or attitude. A high score represents a high level of rebelliousness a participant feels they possess. We measured this variable but using six items from Cloninger, et al (1994) Temperament and Character Inventory. An example question used was: "Know how to get around the rules." $(\mathrm{M}=2.29 ; \mathrm{SD}=.69 ;$ alpha=.76).

\subsubsection{Self-disclosure}

Self-disclosure was measured using eight items from Cloninger, et al (1994) Temperament and Character Inventory. This communication variable tests to find the amount of information one shares with others. This specifically related to our study in that it tested the amount of information one is willing to share with others at the university and how that effects his or her spiritual development. Example questions taken from this Inventory are: "Am open about myself to others" and "Disclose my intimate thoughts." $(\mathrm{M}=3.48 ; \mathrm{SD}=.68$; alpha=.83). 


\subsubsection{Demographics}

The remaining questions on our survey gathered information about the participant's age, class rank, ethnicity, and sex.

\section{Results}

\subsection{Sample Characteristics}

The sample $(\mathrm{N}=149)$ included 98 females and 51 males. They ranged in age from 18 to 42 , with a mean age of 20 (SD $=2.29$ ). There was some ethnic variety in the sample which consisted of $79 \%$ Caucasian and $10 \%$ Hispanic. This is consistent, however, with the over-all university population. In addition, we asked participants to identify their class rank, whether it is that of an underclassman or an upperclassman. There were a total of 60 students that classified themselves as underclassmen, and 89 students who classified themselves as upperclassmen.

Table 2. Correlation Matrix $(\mathrm{N}=149)$

\begin{tabular}{|c|c|c|c|c|c|c|}
\hline Variables & 1 & 2 & 3 & 4 & 5 & 6 \\
\hline 1. Life Satisfaction & -- & & & & & \\
\hline 2. Gregariousness & $.44 * *$ & & & & & \\
\hline 3. Self-disclosure & $.30 * *$ & $.60 * *$ & & & & \\
\hline 4. Rebelliousness & $-.38 * *$ & -.14 & -.15 & & & \\
\hline 5. Traditionalism & $.21 * *$ & $.21 * *$ & $.22 * *$ & $-.41 * *$ & & \\
\hline 6. Spirituality & $.27 * *$ & $.39 * *$ & $.35 * *$ & $-.33 * *$ & $.78 * *$ & -- \\
\hline
\end{tabular}

Note. $* * \mathrm{p}<.01$.

\subsection{RQ1: Student Spirituality}

To answer our first research question we performed a stepwise multiple regression procedure to identify the level of influence each independent variable has on a student's spirituality (see Table 3). We found that two of our independent variables were statistically significant and explained 65 percent of spirituality. Traditionalism explained $60 \%$ of the scores of spirituality and gregariousness explained $5.2 \%$.

Table 3. Stepwise Regression of Spirituality $(\mathrm{N}=149)$

\begin{tabular}{lcccc}
\hline Variables & $\mathbf{R}^{2}$ & $\mathbf{R}^{2} \mathbf{c h a}$ & $\mathbf{b}$ & $\mathbf{t}$ \\
\hline Traditionalism & .60 & .60 & .57 & $14.51^{* * *}$ \\
Gregariousness & .65 & .05 & .21 & $4.65^{* * *}$ \\
\hline
\end{tabular}

Note. Standard Error $=.34 ;$ Adjusted $\mathrm{R}^{2}=.65 ; * * * \mathrm{p}<.001$.

In addition, examination of the beta scores shows the variables' relative contribution to spirituality. A one-unit increase in traditionalism resulted in a .57 increase in spirituality. Also, a one-unit increase in gregariousness resulted in a .21 increase in scores on spirituality.

Inspection of the correlation matrix indicated a high correlation between spirituality and traditionalism (Pearson's $\mathrm{r}=.78$ ). Although scholars differ on the threshold for unacceptable collinearity (see Monge, 1980, and Hair, Anderson, Tatham, \& Black, 1992), we decided to run two additional regression procedures using spirituality and traditionalism, in turn, as the dependent variable, while excluding the other from the independent variable list. The results of those tests appear in Table 4 and indicate that rebelliousness has an inverse relationship with both spirituality and traditionalism scores.

Table 4.

\begin{tabular}{|c|c|c|c|c|}
\hline Variables & $\mathrm{R} 2$ & R2cha & $\mathrm{b}$ & $\mathrm{t}$ \\
\hline Gregariousness & .15 & .15 & .31 & $4.72 * * *$ \\
\hline Rebelliousness & .23 & .08 & -.23 & $-3.77 * * *$ \\
\hline \multicolumn{5}{|c|}{ Note. Standard Error $=.51 ;$ Adjusted R2 $=.21 ; * * * \mathrm{p}<.001$. } \\
\hline Variables & $\mathrm{R} 2$ & R2cha & $\mathrm{b}$ & $\mathrm{t}$ \\
\hline Rebelliousness & .17 & .17 & -.45 & $-5.22 * * *$ \\
\hline Self-Disclosure & .23 & .08 & -.23 & $2.11 *$ \\
\hline
\end{tabular}

Note. Standard Error = .71; Adjusted R2 = .19; *p<.05, ***p<.001. 


\subsection{RQ2 \& H1: Class Rank Comparisons}

To answer our second research question and hypothesis one we ran a t-Test to determine if there was a difference in communication behaviors and personality characteristics and spirituality based on class rank (underclassmen and upperclassmen). This test indicated a statistically significant difference in satisfaction within their lives (Table 5). Upperclassmen have a higher level of satisfaction with their current state in comparison to the underclassmen. Additionally, hypothesis one was not supported. In fact, upperclassmen have a higher score on spirituality than underclassmen, although the difference is not a statistically significant one.

To further explore the possibility of differences based on class rank at a more granular level, we ran a series of ANOVA tests to find significant differences in our variables according to class rank. Examination of Levene's test indicated that the data met the assumptions of ANOVA (Keyton, 2001). A Post Hoc (Tukey HSD) analysis showed that seniors (M = 3.71) reported greater self-disclosure, $\mathrm{F}(3,145)=3.45, \mathrm{p} .=.018$, than first-year students $(\mathrm{M}=3.30)$ or juniors $(\mathrm{M}=$ 3.34).

Table 5. t-Test Comparison of Underclassmen and Upperclassmen

\begin{tabular}{llllll}
\hline & \multicolumn{2}{c}{$\begin{array}{c}\text { Underclassmen } \\
(\mathrm{n}=60)\end{array}$} & \multicolumn{2}{c}{$\begin{array}{c}\text { Upperclassmen } \\
(\mathrm{n}=89)\end{array}$} \\
\hline Variable & Mean & SD & Mean & SD & $\mathrm{t}$ \\
\hline Spirituality & 4.42 & .68 & 4.52 & .50 & -1.01 \\
Satisfaction & 3.79 & .69 & 4.06 & .61 & $-2.51^{*}$ \\
Gregariousness & 3.99 & .75 & 4.09 & .57 & -.94 \\
Traditionalism & 3.96 & .82 & 3.96 & .77 & -.05 \\
Self-disclosure & 3.39 & .72 & 3.54 & .65 & -1.34 \\
Rebelliousness & 2.41 & .80 & 2.21 & .60 & $1.64 \dagger$ \\
\hline
\end{tabular}

Note. $* \mathrm{p}<.05 ; \uparrow \mathrm{p}<.10$.

We also found a statistically significant difference in the comparison between first-year students and both sophomores and juniors in relation to rebelliousness, $\mathrm{F}(3,145)=3.86, \mathrm{p} .=.011$. A Post Hoc (Turkey HSD) analysis revealed that first-year students in our sample $(M=2.57)$ reported higher levels of rebelliousness than either sophomores or juniors $(\mathrm{M}=2.10)$.

\subsection{H2: Comparison of Females and Males}

Our hypothesis predicted that females will score higher than males on spirituality, satisfaction, gregariousness, and traditionalism and will score lower than males on rebelliousness. Table 6 shows the results of a t-Test that was run to show this comparison. After examining our data, we found statistically significant differences between males and females in all of the predicted variables and in the direction predicted with the exception of gregariousness which was not statistically significant. College females tend to be more spiritual, have a higher satisfaction in life, and are more traditional. Males, however, tend to score higher on the rebelliousness scale.

Table 6. t-Test Comparison of Sex Differences

\begin{tabular}{llllll}
\hline & \multicolumn{2}{c}{$\begin{array}{c}\text { Males } \\
(\mathrm{n}=51)\end{array}$} & \multicolumn{2}{c}{$\begin{array}{c}\text { Females } \\
(\mathrm{n}=98)\end{array}$} \\
\hline & Mean & SD & Mean & SD & t \\
\hline Spirituality & 4.32 & .74 & 4.56 & .46 & $-2.09^{*}$ \\
Satisfaction & 3.76 & .72 & 4.05 & .60 & $-2.58^{*}$ \\
Gregariousness & 3.96 & .76 & 4.10 & .59 & -1.20 \\
Traditionalism & 3.74 & .91 & 4.08 & .69 & $-2.32^{*}$ \\
Self-disclosure & 3.41 & .76 & 3.52 & .64 & -.86 \\
Rebelliousness & 2.45 & .65 & 2.20 & .70 & $2.11^{*}$ \\
\hline
\end{tabular}

Note. $* \mathrm{p}<.05$.

\section{Discussion}

\subsection{College Student Spirituality}

This study aimed to find what specific variables strongly influence student spirituality. Our findings supported previous research about traditionalism and gregariousness and how it relates to religiosity. According to previous studies, there is a positive correlation between various measures of spirituality and the use of positive coping, frequency of prayer, and 
the extent to which religion is used to deal with problems (Baesler \& Ladd, 2009). Even if students experience times of distress and doubt, growing up in a traditionalist mode can instill the practice of turning to faith and spirituality in times of distress (MacGeorge, Bodie, Sietman, Geddes, Faris, \& Samter, 2007). Furthermore, this traditionalism only happens in the process of how one is raised in the home growing up. Further, research by Gunnoe, Hetherington and Reiss (1999), found that parents often think that obedience to parental authority will eventually help children to submit to God. Our finding would most likely support research indicating differential effects of parenting style on student spirituality (Baumbach, Forward, \& Hart, 2006).

College students are more likely to follow the traditional ideas and practices of spirituality that are passed on to them through their family (Cureton, 1989). However, some students do rebel against these ideas in college and consequently measure lower on the spirituality scale. Students with higher measurements of rebelliousness also have lower measures of traditionalism as well as spirituality. This makes sense because some students raised in an extremely traditional and authoritarian home, will go the opposite direction almost immediately when they get out from under the ideas and rules of their parents. When students encounter ideas that contradict the traditional views they have grown up with, they may rebel against what their parents have taught them, simply to claim that they are finally making some decisions on their own.

Gregariousness is defined as a general sense of being outgoing, talkative, comfortable around other people and comfortable in engaging and initiating conversation. This seems to support the idea that people who practice living in community and who partake in religious practices within a community, measure higher in spirituality. College students in general place a great emphasis on their social lives and social relationships. At a religious university, particularly the university from which our test subjects came, there is great emphasis on living well in community. Student ministries become not only service in the name of the religion, but also social outings and ways to get connected and make friends. People who are more gregarious are more likely to join these groups and become more connected to people and more committed to the religious cause.

\subsection{Comparison of Upper and Lower Rank Students}

Contrary to some research, our study showed that upper class students (juniors and seniors) had higher spiritual satisfaction scores than did lower class students (first-year and sophomores). Research by Bryant, Choi, and Yasuno (2003) found that seniors in their fourth or fifth year may start to feel suffocated and restricted by their environment and, as a result, become disillusioned by the practices of the university, including religion. These feelings of disenchantment may come simply from fatigue or from negative experiences with the organization resulting in lower commitment to the university (Forward, Daugherty, Michel, \& Sandberg, 2009). However, our study indicates that as students move from freshmen to senior year, they gradually decrease in rebelliousness. This is possible because for many students, especially those raised in traditional households, their first year at college is also their first time being away from home and not under their parents' rules and watchful eyes. This newfound sense of freedom can lead students to rebel in various ways. Often as time goes on, as our study shows, the level of rebelliousness in students in Christian universities decreases as they progress in their years at the university. As students learn about themselves and become more and more independent, they no longer feel the need to rebel because they define their own lives, beliefs, and responsibilities.

In our study, upperclassmen scored higher in self-disclosure. This could be because as their time at the university increases, they get to know better the people around them leading them to feel more comfortable disclosing information about themselves, their lives, and where they are in their faith journey. Greene, Derlega and Mathews (2006), note the importance of appropriate self-disclosure as a part of any meaningful human relationship. Self-disclosure has been linked to increased social support, positive self-worth, and enhanced life satisfaction. Self-disclosure about religion can contribute to a person's psychological well-being. This increased self-worth can also be explained by the meaning found in religion and one's spiritual journey as an individual and with others as they self-disclose.

Freshmen in this stage of entering into young adulthood come with huge changes, which can be either positive or negative. Students are walking a fine line between obedience to their traditional upbringings and a desire for autonomy (Hill \& Holmbeck, 1986). For those students who scored higher in rebelliousness, they may for the first time in their lives be going against the values with which they were raised (Bukobza, 2009). This reaction to freedom resulting in rebellion varies by the individual and the situation, but in our study it does show a negative correlation with spirituality.

\subsection{Comparison of Females and Males}

Our hypothesis explored differences in communication, personality, and spirituality based upon sex. From our research, we were able to conclude that college females at a Christian university tend to be more religious, have higher satisfaction in life, and are more traditional, while males tend to score higher on the rebelliousness scale. Therefore, our results would support previous research by Smith, Faris, Denton and Regnerus (2003) that found that women tend to score higher in spirituality and religiosity no matter what their age or context. This does not necessarily mean that 
females are definitely more spiritual but that they may just be more open about it. Females scored higher on self-disclosure and gregariousness, which could be a reason why they are willing to talk more about their spirituality. Male and female communication and self-disclosure varies. Females tend to self-disclose more information and in a shorter amount of time in their relationships (Forward, Daugherty, Michel \& Sandberg, 2009). This openness in talking about the intimate subject of spirituality, could account for some of the differences in spirituality scores based on sex that our survey shows. Because males scored higher on rebelliousness, they may be more likely to reject the values of the Christian university and therefore do not claim to be as spiritual as females, who score lower on rebelliousness.

\subsection{Conclusion}

This study was undertaken with the belief that spirituality is an important dimension of adolescent development generally and of particular relevance to the college experience (Astin, 2004). This is especially true for conservative Protestant universities whose mission explicitly entails an "intentionally Christ-centered education" (CCCU, 2003). This mission matters since a number of studies have noted the positive behaviors associated with religious belief and activity such as emotional health, volunteer involvement, and family well-being (Forward, Sansom-Livolsi, \& McGovern, 2008; Regnerus, 2003). According to Aiken (2002), religious activity helps people remain engaged in the world and provides a sense of personal and social integration. As Kass and Lennox (2005) argue, these are all desirable outcomes for college educated young people and are relevant to the personal growth and maturation characteristic of late adolescence. As such, this research contributes to our understanding in four ways.

First, our findings highlight the unique importance of the family as an incubator of personal values, beliefs, spirituality, and communication interaction patterns. While this finding is hardly new or unexpected, it provides additional empirical evidence for the collaborative role between parents and the conservative, Protestant university (Ma, 2003). As Mullikin (2006) notes, both students and parents are attracted to church-related institutions because of congruence with personal religious identity and the belief that these schools will provide a safer, more nurturing environment. Although there are many cultural, economic, and governmental factors currently influencing Christian higher education in the U.S., these assumptions continue to be accurate for our sample in this specific context (Glanzer, Carpenter, \& Lantinga, 2011). We encourage student development specialists to be aware of the significant contributions of spirituality and religion to personal growth and development during late adolescence and the role that should be played by the university in this process (Astin, Astin, \& Lindholm, 2011).

Second, our research provides empirical support for the assertion that "intentionally Christ-centered" schools are succeeding in their religious mission. Ma (2003) suggests that the core responsibility of Christian universities is to create educational experiences that develop young Christian adults who will display mature characteristics of a Christian, both intellectually and in terms of self-identity. She also suggests that Christian universities have a unique opportunity to facilitate mature Christian character, religious attitudes, and interpersonal behavior patterns through the college environment (Ma, 2003). Medhurst (2004) describes it as the willful integration of faith and learning in all we do in the Christian university. Indeed, our findings show that, taken as a whole, spirituality scores increased when first-year students and seniors are compared which may reflect the intentional nature of spirituality and religion at conservative, Protestant universities (CCCU, 2003).

Third, our research demonstrates the centrality and importance of communication in managing relationships at both home and in college and achieving higher levels of life satisfaction. High quality communication is especially significant in terms of self-disclosure and gregariousness and the roles they play in negotiating the interpersonal demands of college. Student development directors and resident assistants should consider whether they are creating opportunities for students to develop the communication skills necessary for interpersonal and academic success in and out of the classroom (Wisner, 2011).

Lastly, our findings uncovered differences based on both gender and class rank. A possible response to these differences, according to Welch and Mellberg (2008), would be to implement "developmental, gender-specific programs" that could help to address students' spiritual growth. They stress that it is important to approach males and females differently when talking about and encouraging spiritual growth. They also stress that it is important to do the same in regards to class rank. The experiences and life circumstances of a freshman can be very different than that of a senior student (Granqvist \& Hagekull, 2003). These differences will likely account for variances in the students' own measure of their spirituality and willingness to engage in religion and the practices that go along with it.

\subsection{Limitations and Future Research}

The data collected was from one private Christian university in Southern California. As such, it does not represent the college population in general or even all conservative Protestant institutions. Future research should gather data from multiple religiously affiliated institutions as well as secular schools. It would be relevant to see how students who have grown up in traditional and faith-based backgrounds score on spirituality and religion as they progress through 
education at a nonreligious, secular university.

Also, even though it is representative of the university population that was sampled, the participants were predominantly Caucasian and economically advantaged. More ethnic, geographic, and socio-economic diversity would provide a more accurate reading of religious university students in general.

\section{Acknowledgement}

We thank Derrick Riberio for his help on this project.

\section{References}

Aiken, L. R. (2002). Attitudes and related psychosocial constructs: Theories, assessment, and research. Thousand Oaks, CA: Sage.

Astin, A. W. (2004). Why spirituality deserves a central place in liberal education. Liberal Education, 90(2), 34-41.

Astin, A. W., Astin, H. A., \& Lindholm, J. A. (2011). Assessing students' spiritual and religious qualities. Journal of Student Development, 52(1), 39-61. http://dx.doi.org/10.1353/csd.2011.0009

Baesler, E. J., \& Ladd, K. (2009). Exploring prayer contexts and health outcomes: From the chair to the pew. Journal of Communication \& Religion, 32, 347-374.

Barna Group. (2003). Twenty somethings struggle to find their place in Christian churches. Retrieved from http://www.barna.org/barna-update/article/5-barna-update/127

Baumbach, K., Forward, G. L., \& Hart, D. (2006). Communication and parental influence on late adolescent spirituality. Journal of Communication \& Religion, 29, 394-420.

Birkholz, D. M. (1997). Walking with God: Students' stories of spiritual growth at a small Christian college. Journal of Research on Christian Education, 6(1), 21-47. http://dx.doi.org/10.1080/10656219709484838

Blaikie, N. (2003). Analyzing quantitative data: From description to explanation. London: Sage.

Bobkowski, P. S., \& Kalyanaraman, S. (2010). Effects of online Christian self-disclosure on impression formation. Journal for the Scientific Study of Religion, 49(3), 456-476. http://dx.doi.org/10.1111/j.1468-5906.2010.01522.x

Bryant, A. N., \& Astin, H. S. (2008). The correlates of spiritual struggle during the college years. The Journal of Higher Education, 79(1), 1-27. http://dx.doi.org/10.1353/jhe.2008.0000

Bryant, A. N., Choi, J. Y., \& Yasuno, M. (2003). Understanding the religious and spiritual dimensions of students' lives in the first year of college. Journal of College Student Development, 44(6), 723-745. http://dx.doi.org/10.1353/csd.2003.0063

Bukobza, G. (2009). Relations between rebelliousness, risk-taking behavior, and identity status during emerging adulthood. Identity: An International Journal of Theory and Research, 9(2), 159-177. http://dx.doi.org/10.1080/15283480802676932

Clark, L. S. (2002). U. S. adolescent religious identity, the media, and the "funky" side of religion. Journal of Communication, 52(4), 794-811. http://dx.doi.org/10.1111/j.1460-2466.2002.tb02574.x

Cloninger, C. R., Przybeck, T. R., Svrakic, D. M., \& Wetzel, R. D. (1994). The Temperament and Character Inventory (TCI): A guide to its development and use. St. Louis, MO: Center for Psychobiology of Personality, Washington University.

Council for Christian Colleges \& Universities. (2010). About CCCU. Retrieved from http://www.cccu.org/about

Council for Christian Colleges \& Universities. (2003). The news and people of Christ-centered higher education. [Brochure]. Washington, DC: Falck.

Cureton, A. S. (1989). Spiritual development: A descriptive study of college freshmen at a selected institution of the Christian College Coalition (Doctoral dissertation, Iowa State University, 1989). Dissertation Abstracts International, 50(06)A, 1575.

Dennis, D., Muller, S. M., Miller, K., \& Banerjee, P. (2004). Spirituality among a college student cohort: A quantitative assessment. American Journal of Health Education, 35(4), 220-227. http://dx.doi.org/10.1080/19325037.2004.10603645

Eckel, M. (2009). A Comparison of Faith-Learning Integration between Graduates of Christian and Secular Universities in the Christian School Classroom (Doctoral dissertation, The Southern Baptist Theological Seminary). Dissertation Abstracts International, 71(06), 3411372. 
Eckstein, N. J., \& Truman, P. D. (2002). “Children are to be seen and not heard:” Silencing students' religious voices in the university classroom. Journal of Communication and Religion, 25, 166-192.

Fisler, J., Agati, H., Chance, S. M., Donahue, A. E., Donahue, G. A., Eickhoff, E. J., \& Foubert, J. D. (2009). Keeping (or losing) the faith: Reflections on spiritual struggles and their resolution by college seniors. College Student Affairs Journal, 27(2), 257-274.

Forward, G. L., Czech, K., \& Allen, P A. (2007). Leadership, communication and religiosity in higher education administration: Distinctions that make a difference. Journal of Communication \& Religion, 30, 153-185.

Forward, G. L., Daugherty, N., Michel, H., \& Sandberg, D. (2009). The effects of communication, religiosity, and organizational support on student commitment at a church-related university. Human Communication, 12(1), $33-52$.

Forward, G. L., Sansom-Livolsi, A., \& McGovern, J. (2008). College student communication, religiosity and family satisfaction: The importance of opposite-sex parent relationships. Journal of Communication \& Religion, 31, 245-271.

Glanzer, P. L., Carpenter, J. A., \& Lantinga, N. (2011). Looking for God in the university: Examining trends in Christian higher education. Higher Education: The International Journal of Higher Education and Educational Planning, 61(6), 721-755. http://dx.doi.org/10.1007/s10734-010-9359-x

Granqvist, P, \& Hagekull, B. (2003). Longitudinal predictions of religious change in adolescence: Contributions from the interaction of attachment and relationship status. Journal of Social and Personal Relationships, 20(6), 793-817. http://dx.doi.org/10.1177/0265407503206005

Greene, K., Derlega, V. J., \& Mathews, A. (2006). Self-disclosure in personal relationships. In A. L. Vangelisti \& D. Perlman (Eds.), The Cambridge handbook of personal relationships (pp. 409-427). NewYork: Cambridge University Press.

Greydanus, D. E., Pratt, H. D., Patel, D. R., \& Sloane, M. (1997). The rebellious adolescent: Evaluation and management of oppositional and conduct disorders. Pediatric Clinics of North America, 44, 1457-1485. http://dx.doi.org/10.1016/S0031-3955(05)70569-1

Griffin, E. (2004). A believer's attempt to integrate faith and scholarship. Journal of Communication \& Religion, 27, 25-31.

Gunnoe, M., Hetherington, E., \& Reiss, D. (1999). Parental religiosity, parenting style, and adolescent social responsibility. Journal of Early Adolescence, 19(2), 199-225. http://dx.doi.org/10.1177/0272431699019002004

Hair, J., Anderson, R., Tatham, R., \& Black, W. (1992). Mutlivariate data analysis with readings (3rd ed.). New York, NY: Macmillan.

Hart, J. T., Limke, A., \& Budd, P. R. (2010). Attachment and faith development. Journal of Psychology and Theology, $38,122-128$.

Henck, A. (2011). Walking the tightrope: Christian colleges and universities in a time of change. Christian Higher Education, 10(3-4), 196-214. http://dx.doi.org/10.1080/15363759.2011.577711

Hill, J., \& Holmbeck, G. (1986). Attachment and autonomy during adolescence. In G. Whitehurst (Ed.), Annuals of child development (Vol. 3, pp. 145-189). Greenwich, CT: JAI Press.

Jackson, D. N. (1994). Jackson Personality Inventory-Revised manual. Port Huron, MI: Sigma Assessment Systems.

Jackson, D. N., Paunonen, S. V., \& Tremblay, P. F. (2000). Six Factor Personality Questionnaire Manual. Port Huron, MI: Sigma Assessment Systems.

Judge, W. Q. (1999). The leader's shadow: Exploring and developing executive character. Thousand Oaks: Sage.

Kass, J., \& Lennox, S. (2005). Emerging models of spiritual development: A foundation for mature, moral, and health-promoting behavior. In W. R. Miller \& H. Delaney (Eds.), Judeo-Christian perspectives on psychology: Human nature, motivation, and change. Washington, D.C.: American Psychological Association. http://dx.doi.org/10.1037/10859-010

Keyton, J. (2001). Communication research: Asking questions, finding answers. New York: McGraw-Hill.

Kind, P. E. (2003). Religion and identity: The role of ideological, social, and spiritual contexts. Applied Developmental Science, 7, 196-203.

King, P. E., \& Boyatzis, C. J. (2004). Exploring adolescent spiritual and religious development: Current and future 
theoretical and empirical perspectives. Applied Developmental Science, 8(1), 2-6. http://dx.doi.org/10.1207/S1532480XADS0801_1

Lee, J. L. (2002). Religion and college attendance: Change among students. The Review of Higher Education, 25, 369-384. http://dx.doi.org/10.1353/rhe.2002.0020

Ma, S. (2003). The Christian college experience and the development of spirituality among students. Christian Higher Education, 2, 321-339. http://dx.doi.org/10.1080/15363750390246097

MacGeorge, E. L., Bodie, G. D., Sietman, G. B., Geddes, B., Faris, J. L., \& Samter, W. (2007). Individual prayer behavior in times of personal distress: Typological development and empirical examination with a college student sample. Journal of Communication \& Religion, 30, 1-39.

Maltby, J., \& Day, L. (2003). Religious orientation, religious coping and appraisals of stress: Assessing primary appraisal factors in the relationship between religiosity and psychological well-being. Personality \& Individual Differences, 34, 1209-1224. http://dx.doi.org/10.1016/S0191-8869(02)00110-1

Mannoia, V. J. (2000). Christian liberal arts: An education that goes beyond. Lanham, MD: Rowan and Littlefield.

McNamee, L. G. (2011). Faith-based organizational communication and its implications for member identity. Journal of Applied Communication Research, 39, 422-440. http://dx.doi.org/10.1080/00909882.2011.608697

Medhurst, M. J. (2004). Religious belief and scholarship: A complex relationship. Journal of Communication \& Religion, 27, 40-47.

Monge, P. R. (1980). Multivariate multiple regression. In P. R. Monge \& C. N. Capella (Eds.), Multivariate techniques in human communication research (pp. 13-56). New York: Academic Press.

Mullikin, P. L. (2006). Religious and spiritual identity: The impact of gender, family, peers, and media communication in post-adolescence. Journal of Communication and Religion, 29, 178-203.

Nunnally, J. C. (1978). Psychometric theory. New York: McGraw-Hill.

Okulicz-Kozaryn, A. (2010). Religiosity and life satisfaction across nations. Mental Health, Religion \& Culture, 13(2), 155-169.

Peterson, C., \& Seligman, M. E. P. (2004). Character strengths and virtues: A handbook and classification. New York: Oxford University Press.

Prothero, S. (2007). Religious literacy: What every American needs to know-and doesn't. New York: HarperOne.

Regnerus, M. D. (2003). Religion and positive adolescent outcomes: A review of research and theory. Review of Religious Research, 44(4), 394-413. http://dx.doi.org/10.2307/3512217

Silva, D., \& Sias, P. M. (2010). Connection, restructuring, and buffering: How groups link individuals and organizations. Journal of Applied Communication Research, 38, 145-166. http://dx.doi.org/10.1080/00909881003639510

Sloat, D. F. (1986). The dangers of growing up in a Christian home. Nashville, TN: Thomas Nelson.

Smith, C., Denton, M., \& Regnerus, M. (2002). Mapping American adolescent religious participation. Journal for the Scientific Study of Religion, 41, 597-612. http://dx.doi.org/10.1111/1468-5906.00148

Smith, C, Faris, R., Denton, M., \& Regnerus, M. (2003). Mapping American adolescent subjective religiosity and attitudes of alienation toward religion: A research report. Sociology of Religion, 64(1), 111-133. http://dx.doi.org/10.2307/3712271

Tajfel, H., \& Turner, J. C. (1986). The social identity theory of intergroup behavior. In S. Worchel (Ed.), Psychology of intergroup relations $\left(2^{\text {nd }}\right.$ ed.) (pp. 7-24). Chicago: Nelson-Hall.

Welch, R. D., \& Mellberg, K. (2008). Spiritual maturation and religious behaviors in Christian university students. Christian Higher Education, 7, 142-161.

Wisner, M. D. (2011). Psychological strengths as predictors of effective student leadership. Christian Higher Education, 10, 353-375. http://dx.doi.org/10.1080/15363759.2011.576223

Young, J. S., Cashwell, C. S., \& Shcherbakova, J. (2000). The moderating relationship of spirituality on negative life events and psychological adjustment. Counseling \& Values, 45, 49-57. http://dx.doi.org/10.1002/j.2161-007X.2000.tb00182.x

\section{(cc) $\mathrm{BY}$}

This work is licensed under a Creative Commons Attribution 3.0 License. 